\title{
The Development of English Teaching/Learning Materials Relevant to Chinese College Students
}

\author{
Xu Wenjun \\ College of Liberal Arts and Law, Inner Mongolia Radio \& TV University \\ 34 Xinhua East Street, New City District, Hohhot, Inner Mongolia, China \\ Tel: 86-130-7476-5734Ｅ-mail: xwnjn@aliyun.com
}

Received: November 5, 2016 Accepted: November 23, 2016 Published: November 28, 2016

doi:10.5296/ijele.v5i1.10373 URL: http://dx.doi.org/10.5296/ijele.v5i1.10373

\begin{abstract}
The author briefly states the current state at home and abroad of the development and use of English teaching/learning materials relevant to students, and the significance of developing English teaching/learning materials relevant to Chinese college students. The designing of this development of materials relevant to Chinese college students, consisting of creating a series of mini-stories about them and colleting materials interesting to them, is discussed. The factors considered when the series of mini-stories are written are stated. The examples of the materials developed are given. The problems encountered during the writing of the mini-stories, the solutions found and the findings of trial use are briefly discussed.
\end{abstract}

Keywords: materials relevant to students, designing, development, trial use 


\section{Introduction}

I have been an English teacher in China for about 12 years. Among the many courses I teach are English writing and oral English courses. When I ask students to write or say something, they often do not have the words. It is mainly because the textbook materials are largely irrelevant to them, and they can not find the words to express themselves in the books. This prompted me to think about developing materials relevant to students by myself years ago. But due to limited vocabulary then, I could not do it right away. I read English online, and made friends with English speakers to practice my oral English. Gradually, I learned enough English words to enable me to write about students in English. I would like to share my thoughts and ideas on the development of such materials in this paper. Although the materials are developed in the Chinese context, I think that the ideas behind it can be applied to foreign contexts too.

\section{The Current State at Home and Abroad of the Development and Use of English Teaching/Learning Materials Relevant to Students}

\subsection{Abroad}

Some parts of a paper by McKay (2004) will be quoted to look at the current state abroad of the development and use of English teaching/learning materials relevant to students. While McKay looked at English teaching/learning materials from the cultural point of view, what she said will be interpreted from the viewpoint of the materials' relevance to students. This paper talks about the materials most relevant to students, the things they are interested in, the events they experience, their concerns and the issues facing them, instead of their culture.

McKay said in the paper: "In many countries, the teaching of English is becoming much more closely aligned with the host culture as those countries use local characters, places, and issues as the content for their teaching materials."

From this quote, we can see that many countries use the materials describing the life of the local people as the content for their teaching/learning materials.

One of the examples she gave in the paper is Chile.

She said: "In Chile, the Ministry of Education has decided that it would be motivating for students to focus on their own culture and country. Hence, the Ministry has designed a series of textbooks for the public schools entitled Go for Chile that implements the Ministry's learning objectives. Go for Chile features a group of students from various countries on board a ship sailing along the coast of Chile. The scenario of the sea voyage enables the textbook writers to deal with Chilean places and concerns. Thus, the book is filled with information about various areas of Chile and issues facing the country."

This quote can be summarized that Chile considers the materials talking about the Chilean places and people motivating for their students, and they developed a series of textbooks for the public schools entitled Go for Chile which deal with Chilean places and concerns, and 
that Chile uses materials about Chile as their English textbook content.

When she talked about English-teaching in Morocco, she said: "The teachers believe that students will be more, not less, motivated to learn English if the language is presented in contexts that relate to their lives as young adults rather than in the context of an English-speaking country."

From this quote, we can see that if the materials are directly related to the students' life, students can be more motivated.

From the three quotes, I can conclude that many countries use the materials describing the life of the local people as the content for their teaching/learning materials, and I can also conclude that English teaching/learning materials should be about the country where English is taught, and more importantly, they should be about the students themselves. Only when the materials describe the life of the students in that country, the materials can be most relevant to them, thus most motivating for them.

\subsection{At Home}

In China, there are no college English textbooks which use materials relevant to students as the content. And there is also no research on it. Some of the content of the college English textbooks is copied from foreign books, and is not suitable for Chinese students. For example, in some college English textbooks, some debate topics are euthanasia, abortion and homosexuality. While they are controversial abroad, they are not in China. Many students are not interested in them. If they can be changed to filial piety, one-child policy and love and be loved, students will be more interested.

\section{Lack of English Teaching/Learning Materials Relevant to Students Hampers the English Teaching/Learning in China}

Due to the lack of content related to students' life in English textbooks in China, students can not find in their books English vocabulary they need to express themselves. When students are asked to say something or write something, they just do not have the words. Many Chinese students think that studying English is a big headache. Chinese students get poor test results. Statistics show that on average, graduating college students in Hong Kong and the Philippines get 6.1 on IELTS, while their counterparts in China score 4.1.

\section{The Significance of Developing English Teaching/Learning Materials Relevant to Chinese College Students}

Due to the backwardness of English teaching in China, Chinese people's English has become the butt of jokes abroad. In an American TV series called Bones, there is an episode in which an American woman bought a made-in-China stroller, but she could not understand the English instructions on how to assemble it because of the poor English. Some of my American friends find it very laughable. 
The significance of developing English teaching/learning materials relevant to Chinese college students is to increase the effectiveness and the usefulness of English teaching/learning and to increase students' interest in English. And hopefully it will help raise the standard of English teaching/learning in China, and narrow the gap between China and foreign countries in English teaching/learning.

\section{The Development of English Teaching/Learning Materials Relevant to Chinese College Students}

\subsection{The Designing of the Development of Such Materials}

\subsubsection{Write a Series of Mini-stories about Contemporary Chinese College Students}

The author uses a male Chinese college student as a protagonist, starting to write about him from the National College Entrance Exams. When he arrives at the university, the author starts to write about his studies and life of him and of his three roommates. The stories are based on the events happening in their life and issues facing them. The titles of the stories are college events and issues. The stories span the first four semesters because non-English majors study general English for the first four semesters. They have one English class each week, and they have 18 weeks each semester. If you subtract 3 weeks when they have to review and take the final exam, and a holiday falls on the day of class, they have only 15 weeks to study new material each semester. One story for each class, 15 stories for each semester have been prepared. In the beginning, the stories are about events all Chinese college students experience, and each of them is timed to be studied around the time the real event happens in their life, so that they can use the words they learn from it to describe their own life right away.

Use the first semester as an example: story 1---study for the National College Entrance Exams, story 2---take the National College Entrance Exams and be accepted into university, story 3---travel to school, story 4---check in at the university, story 5-meet classmates, story 6---the college's first meeting for its incoming freshmen, story 7---military training, story 8---have classes, story 9---the Mid-Autumn Festival and the National Day Holidays, story 10---the election of the group committee and the Communist Youth League branch, story 11---ball games, story 12---a day in the protagonist's life, story 13---the get-together of students from the home province, story 14---the final exams, story15---go home.

Thus after students read each story, they can talk about what just happened, or is happening, or is going to happen soon, using the English words they learn from each story. This way students can use what they learn right away, thus the language comes alive. In the meantime, their studying and living environment, such as flowers, grass and trees, the card games they like to play, and cafeteria food, and etc can be described in the stories. In short, through the stories, whatever they want to say in real life is expressed in English.

As time goes on, the new events to write about will gradually run out. For example, after the first semester, one need not write about ball games and the final exams again, though they 
happen again and again each semester, because they were already written about for the first semester. Then dating and some things students are concerned about, like social skills, failing a course, cafeteria food, scholarships, etc. are written about in the form of stories.

\subsubsection{Collect Some Materials Interesting to Chinese College Students}

After the story, some other materials interesting to them can be added to the lesson. For example:

a. grasp the characteristic of college students loving music, find some melodic romantic songs, so students can learn English while enjoying listening to the songs, thus nurturing their interest in English.

b. use some English brainteasers, and let students feel that there is intelligence hidden in the language.

c. add some very good foreign English stories, such as: Eleanor Estes' The Hundred Dresses, O Henry's The Last Leaf and The Gift of the Magi, etc., to let students feel that there are feelings and morals deeply hidden in the English language. Thus they can appreciate the English language while studying it. They may even remember some of lines the characters say in the stories.

d. prepare some topics students like to talk about, such as: annual university rankings, the Top 10 rich Chinese on Hurun List 2015, Love and be loved, etc., to foster students' interest in oral English.

\subsection{The Factors Considered When the Series of Mini-stories about Chinese College Students Are Written}

\subsubsection{The Stories Should be Positive}

Before starting to write the stories, the themes of the stories have to be decided. If the focus is on negatives, such as: students do not study, they skip class, play computer games too much, roommates do not get along, and they fight, it will have a negative effect on students' studies and life. So it was decided that the themes of the stories should be healthy, uplifting, refreshing and warm. Students can talk about the negative aspects in their life related to the topic of the story, and give their opinion on them. And there are negatives mentioned in passing. But negatives do not dominate the stories. The focus is on positives. So the stories can guide students to live a healthy life in college.

\subsubsection{The Stories Should be Contemporary}

There is a lot of new English vocabulary related to the cell phone and the computer, and it can not be found in English textbooks and dictionaries, such as: cell phone, smart phone, text, speed dial, chat on WeChat, WeChat group, qq group, search engine, and email, etc. But students use cell phones and computers a lot, and they need the English vocabulary in these fields to express themselves. So it was decided to write about contemporary Chinese college students, in order to introduce the English vocabulary in these fields. 
4.2.3 The Stories Should be Interesting and Useful in Helping Students Learn to Express Themselves

To increase the interest of the stories, it was decided to write in a light, not too serious, way. Let students learn the vocabulary from the stories to describe their life while being entertained a little. Thus interest can be combined with usefulness.

\subsubsection{The Stories Should Include Multiple Types of Chinese College Students}

In the beginning, the stories are about the protagonist, one male student. Then when he gets to the university, the stories are about him and his three roommates, and are about typical male students. The stories can't reflect the characteristics of female students' life. To do that, one of his roommates starts to date a girl in the beginning of the fourth semester. Through writing about her, the life of female students can be reflected. Thus there is the life of both boys and girls in the stories, and students will like to read them.

Also, it was deliberately decided that one of the roommates is from the country, and the other three are from cities. So there are country and city boys in the stories. Among the four roommates, some study very hard to earn scholarships, and some just try to do the minimum to pass the courses; each of them has different interests and so on and so forth.

Thus there are both country and city boys, both boys and girls, hard-working and less hard-working students in the stories, etc. Students can therefore find some characters in the stories to identify with.

\subsection{The Examples of the English Teaching/Learning Materials Developed}

Sixty stories were written for this project, 15 stories for each semester, 60 stories for four semesters. And a lot of materials were collected that are interesting to Chinese college students. Here are some examples of them.

\subsubsection{Example 1: One of the Mini-stories}

\section{The College's First Meeting for Its Incoming Freshmen}

The class of 2011 in the Coal Chemical Engineering Department is divided into four groups, CCE111, CCE112, CCE113 and CCE114, each group with 30 students. A Counselor is in charge of the four groups. He appoints a provisional group monitor for each group until an election of group leaders can be arranged.

Li Hai and his roommates are assigned to GroupCCE112. At the end of the check-in period, their provisional group monitor, who lives next door, comes to their dormitory room and tells them that tomorrow morning they are to attend a meeting for all incoming freshmen.

The meeting opens with a speech by the Dean of the College.

First, let me give you a warm welcome on behalf of the leaders of our College. Dalian University of Technology is a comprehensive key university under the administration of the education ministry, with 11 colleges, 12,000 undergraduate students, 6,000 graduate students and 2,000 doctoral students. Our college, one of 11, has 7 departments. 
He discusses the teachers - how many doctoral and graduate supervisors the University and the college have, the national scientific and technological awards they have won, etc. - and then summarizes:

The achievements of our teachers are many. Our laboratory equipment is advanced. The job prospects of our student are better than in most other universities, even though the overall employment situation for college graduates is very difficult throughout China due to the greatly increased university enrollment over the past decade.

I hope that you will cherish your opportunities here. Don't waste time, work hard to repay your cultivation by the motherland.

Then the Party secretary gives his speech:

You come to the university to study at a time when our economy is growing rapidly, taking off. We are now striving to move from a labor-intensive economy to a knowledge-based one. In the future, as we climb the economic ladder, our economic growth will depend more and more on knowledge. That is why the government is investing heavily in education and expanding university enrollment rapidly. You must understand your historical mission in upgrading our economy through knowledge. You must work hard for the future of our motherland.

Most of you are from one-child families; all of you are in a period of transition, from dependence on your parents to being on your own. You have to take on responsibilities; you have to wash your own clothes and dishes, you have to eat on time, go to class on time; you have to avoid becoming addicted to computer games. Learn to discipline yourselves and never lose your focus on your studies.

As the saying goes, at home, depend on parents; outside of the home, depend on friends. If you are sick, can you count on your parents to take care of you? No, you turn to your classmates for help. If there is bad blood between you and your roommate, and you still have to live in the same room and there is no getting away from each other, your life will be miserable. So it is important to get along with others. You must understand that everyone wants friendship as much as you do. Maybe there will be personality conflicts, but if you understand that other people want to make friends with you, you will become more accommodating, overcome the problems and become friends. You will find that the friendships you develop in the university are genuine and precious. They may last a lifetime.

He gives a brief account of the University's history, and then concludes:

Unity, friendship and hard work will make your university life fulfilling and happy.

Li Hai finds the meeting encouraging and informative. He thinks the talk on unity and friendship is especially to the point. He must develop good relationships with classmates. And he has to study hard to live up to his parents' expectations.

\subsubsection{Example 2: A Brainteaser}

You are on the way to a faraway village. Now you have reached a fork. 
There are identical twins there: one standing on the road to the village and the other standing on the road to neverland (of course, you don't know or see where each road leads).

One of the sisters always tells the truth and the other always lies (of course, you don't know who is lying).

Both sisters know where the roads go.

If you are allowed to ask only one question to one of the sisters to find the correct road to the village, what is your question?

\subsubsection{Example 3: The Plots of Three Very Good Foreign English Stories}

\section{A. O Henry's The Last Leaf}

\section{Plot}

A woman nicknamed Johnsy (Joanna in modern English) has come down with pneumonia, and is now close to death. Outside the window of her room, the leaves fall from a vine. Johnsy decides that when the last leaf drops, she too will die, while her best friend Sue, who stays with her, tries to tell her to stop thinking so pessimistically.

In the same apartment building, an elderly, frustrated artist named Behrman lives below Johnsy and Sue. Behrman has been claiming that he will paint a masterpiece, even though he has never even attempted to start. Sue visits Behrman, telling him that Johnsy, who is dying of pneumonia, is losing her will to live. Sue tells Behrman that Johnsy claims that she will die when the last leaf falls off of the vine outside her window. Behrman scoffs at this as foolishness, but - as he is protective of the two young artists - he decides to visit Johnsy and see the vine from her window.

In the night, a very bad storm comes and wind is howling and rain is splattering against the window. Sue closes the curtains and tells Johnsy to go to sleep, even though there is still one leaf left on the vine. Johnsy protests against having the curtains closed, but Sue insists on doing so because she doesn't want Johnsy to see the last leaf fall. In the morning, Johnsy wants to see the vine to be sure that all the leaves are gone, but to their surprise, there is still one leaf left.

While Johnsy is surprised that it is still there, she insists it will fall that day. But it doesn't, nor does it fall through the night nor the next day. Johnsy believes that the leaf stayed there to show how wicked she was, and that she sinned in wanting to die. She regains her will to live, and makes a full recovery throughout the day.

In the afternoon, a doctor talks to Sue. The doctor says that Mr. Behrman has come down with pneumonia and, as there is nothing to be done for him, he is being taken to the hospital to be made comfortable in his final hours. A janitor had found him helpless with pain, and his shoes and clothing were wet and icy cold. The janitor couldn't figure out where he had been on that stormy night, though she had found a lantern that was still lit, a ladder that had been moved, some scattered brushes, and a palette with green and yellow colors mixed on it. "Look out the window, dear, at the last ivy leaf on the wall. Didn't you wonder why it never 
fluttered or moved when the wind blew? Ah, darling, it's Behrman's masterpiece - he painted it there the night that the last leaf fell."

\section{B. O Henry's The Gift of the Magi}

Plot

Mr. James Dillingham ("Young Jim") and his wife, Della, are a couple living in a modest apartment. They have only two possessions between them in which they take pride: Della's beautiful long, flowing hair, almost to her knees, and Jim's shiny gold watch, which had belonged to his father and grandfather.

On Christmas Eve, with only $\$ 1.87$ in hand, and desperate to find a gift for Jim, Della sells her hair for $\$ 20$ to a nearby hairdresser named Madame Sofronie, and eventually finds a platinum pocket watch fob chain for Jim's watch for \$21. Satisfied with the perfect gift for Jim, Della runs home and begins to prepare pork chops for dinner.

At 7 o'clock, Della sits at a table near the door, waiting for Jim to come home. Unusually late, Jim walks in and immediately stops short at the sight of Della, who had previously prayed that she was still pretty to Jim. Della then admits to Jim that she sold her hair to buy him his present. Jim gives Della her present - an assortment of expensive hair accessories (referred to as "The Combs"), useless now that her hair is short. Della then shows Jim the chain she bought for him, to which Jim says he sold his watch to get the money to buy her combs. Although Jim and Della are now left with gifts that neither one can use, they realize how far they are willing to go to show their love for each other, and how priceless their love really is.

The story ends with the narrator comparing the pair's mutually sacrificial gifts of love with those of the Biblical Magi.

\section{Eleanor Estes'The Hundred Dresses}

Plot

The book centers on Wanda Petronski, a poor and friendless Polish-American girl. Her teacher, outwardly kind, puts her in the worst seat in the classroom and she does not say anything when her schoolmates tease her. One day, after Wanda's classmates laugh at her funny last name and the faded blue dress she wears to school every day, Wanda claims to own one hundred dresses, all lined up in her closet at her worn-down house. This outrageous and obvious lie becomes a game, as the girls in her class corner her every day before school, demanding that she describe all of her dresses for them. She is mocked, and her father, Mr. Petronski, decides that she must leave that school.

The teacher holds a drawing contest in which the girls are to draw dresses of their own design. Wanda enters and submits one hundred beautiful designs. Her classmates are in awe of her talent and realize that these were her hundred dresses. Unfortunately, she has already moved away and does not realize she won the contest.[4]

The students who teased her feel remorse and want her to know this, but they are not sure how. They decide to write her a kind letter and send it to her old address, hoping the post 
office can forward it.

\subsubsection{Example 4: A Melodic Song with Romantic Lyrics}

MLTR's Fairy Tale (I choose this song as an example because people in China like this song, and they can access the mp3 of this song online for free easily)

In that misty morning when I saw your smiling face

You only look at me and I was yours

But when I turn around you were nowhere to be seen

You have walked away and closed the door

[Chorus:]

When will I see you again

When will the sky start to rain

When will the stars start to shine

When will I know that you are mine

Did I ever meet you in the sunshine

And when we were both a thousand years away

Did I ever hold you in the moonlight

Did we make every minute last another day

On a cold December night I gave my heart to you

And by the summer you were gone

Now as the days grow older and the stars will start to dim

All I have are memories and this song

[Chorus:]

When will I see you again

When will the sky start to rain

When will the stars start to shine

When will I know that you are mine

Did I ever meet you in the sunshine

And when we were both a thousand years away

Did I ever hold you in the moonlight

Did we make every minute last another day

[Chorus:]

When will I see you again

When will the sky start to rain

When will the stars start to shine

When will I know that you are mine

In that misty morning I saw your smiling face

4.3.5 Example 5: An Article on University Rankings

China overtakes Japan as Asia's No.1 in Times university rankings 


\section{Macrothink}

Chinese institutions outnumber Japanese ones for the first time in the annual Times Higher Education Asia University Rankings, released on Thursday. China has overtaken Japan as Asia's No 1 nation for world-class universities, according to the Asia University Rankings 2015 published on Wednesday by Times Higher Education, a weekly magazine published in the UK.

Twenty-one universities from the Chinese appear in the top 100, up from 18 last year, with Peking University taking fourth place and Tsinghua University one place behind.

China's special administrative regions also do well, with six universities from Hong Kong including two in the top 10 - and one from Macao in the top 50.

The University of Tokyo remains Asia's No 1 institution, but Japan has slipped to second place in the rankings with 19 representatives in the top 100, down from 20 last year.

"This really is China's year, with three new entrants and some of the country's established universities climbing up the tables," said Phil Baty, editor of the Times Higher Education Rankings.

Baty said the results prove that a serious commitment to higher education from a government that is prepared to invest in research and development really does pay off.

The Asia rankings use 13 performance indicators to examine each university's strengths in the core missions of teaching, research, knowledge transfer and international outlook, according to Times Higher Education.

\subsubsection{Example 6}

Top 10 rich Chinese on Hurun List 2015
a. Li Hejun
Company: Hanergy Holdings Group Limited

Assets: 160 billion yuan

b. Wang Jianlin's family Company: Dalian Wanda Group

Assets: 155 billion yuan

c. Jack Ma

Company: Alibaba Group Holding Ltd

Assets: 150 billion yuan

d. Zong Qinghou's family Company: Wahaha Group

Assets: 120 billion yuan

e. Li Yanhong's family Company: Baidu Inc

Assets: 110 billion yuan

f. Ma Huateng

Company: Tencent

Assets: 100 billion yuan 
g. Lei Jun (tied) Company: Beijing Xiaomi Technology Co Ltd

Assets: 85 billion yuan

h. Yan Jiehe's family (tied) Company: China Pacific Construction Group

Assets: 85 billion yuan

i. Yan Bin Company: Reignwood Group

Assets: 59 billion yuan

j. He Xiangjian's family Company: Midea

Assets: 51 billion yuan

\section{The Problems Encountered and Solutions Found When the Mini-stories Are Written}

Because the Chinese educational system is very different than those in most of English-speaking countries, some Chinese educational terms have no English equivalents.

For example, there is a person in charge of usually one class of 120 or 150 students in a department in China's universities. He makes his students exercise in the morning, go to class, keep their dorm rooms clean, do their homework, get along with each other, be quiet and go to sleep after lights-out, listen to the teacher carefully in class. He tries to be in close contact with his students by talking to them and even playing with them in order to know what they are thinking and what their problems are so as to guide them accordingly and help solve their problems. He also disciplines them if they break school rules, organizes cultural and sports activities and the awarding of scholarships for them, etc. They are called "fudaoyuan" in Chinese. But there are no people like them in English-speaking countries' universities. When an American teacher was consulted, he said that the closest word for it is counselor, but in America counselors only give advice to students when they go to counselors to talk about their problems. Then he added "counselor" can be used for it.

Another Chinese term "banzhuren" is a person in charge of a group of students. It is hard to find an English equivalent. When it was searched for on the Internet, it was found that only in Ireland do they have people like that in some of their schools, and they are called "class teachers" there. But Ireland is a small country, and their English does not have much influence. When some Americans were asked about it, they said they don't know what the term "class teacher" means. One American friend who has worked in the local universities for years called this kind of person "head teacher". So they were called either "class teacher" or "head teacher".

Some Chinese terms are hard to translate into English, because the choice of words and word order can be different in the two languages. For example, there is a document called "proof of financial needs" poor college students obtain from their hometown government so that they can use it to take out a loan and apply for needs-based scholarships. If the Chinese term is translated word for word, it is 'poverty proof'. When I asked my American friends about it, 


\section{Macrothink}

one said, "the word 'proof' is always first."So "proof of poverty" was said. Another American said, "It still does not sound right. It should be "proof of financial needs"."

An online journal paper (Kitao and Kitao) says that materials developed should have correct, natural, current and standard English.

To ensure that, foreign friends are often consulted and asked to help polish the materials that have been developed. Special thanks to them.

\section{The Findings of the Trial Use of the Materials that Have Been Developed}

During the trial use, good results have been achieved---students are more motivated to study the materials, their class attendance improves, they grasp the content of each lesson better, and they test better.

\section{Summary and Conclusion}

Based on the life of four college roommates, a series of English mini-stories are written about them. The purpose is to say in the stories whatever Chinese college students want to say in their real life so that they can find the English words in the stories to express themselves. So when they speak English, they don't have to worry about having no English words. Also the major points and aspects of their life were covered. This way students can learn the vocabulary on every aspect of their life. In addition, every story about a college event is timed to be read around the time the real event happens in their life, and the story describes their life at the time they read it. So that after reading it, students can use the words they learn from it to describe their life right away.

The stories are also all based on real stories so that they can resonate with students.

In the meantime, a lot of materials interesting to Chinese college students are collected, including melodic English songs with romantic lyrics, good foreign English stories, and oral English topics.

During the process of developing the materials, foreign English experts are frequently consulted to ensure they are in correct, natural, current and standard English.

During the trial use, positive results are achieved.

Although the materials are developed in the Chinese context, I think that the ideas behind it can be applied to foreign contexts too.

\section{Acknowledgements}

Rowell Hoff and Caroline Hoff helped with English questions and polished the English. Special thanks to them. 


\section{Macrothink

\section{References}

McKay, S. L. (2004). Western culture and the teaching of English as an international language. English Teaching Forum, 42(2), 11-14.

Kitao, K., \& S. K. Kitao. Selecting and developing teaching/learning materials. The Internet TESL Journal. http://iteslj.org/Articles/Kitao-Materials.html (accessed May 12, 2016)

\section{Copyright Disclaimer}

Copyright for this article is retained by the author(s), with first publication rights granted to the journal.

This is an open-access article distributed under the terms and conditions of the Creative Commons Attribution license (http://creativecommons.org/licenses/by/3.0/). 